\title{
Alkane composition variations between darker and lighter colored comb beeswax*
}

\author{
Dvory NAMDAR ${ }^{\mathrm{a}, \mathrm{b}}$, Ronny NEUMANN ${ }^{\mathrm{c}}$, Yossi SLADEZKI ${ }^{\mathrm{d}}$, Nizar HADDAD ${ }^{\mathrm{e}}$, \\ Steve WEINER ${ }^{\mathrm{a}, \mathrm{f}}$
}

\footnotetext{
${ }^{a}$ Kimmel Center of Archaeological Sciences, Weizmann Institute of Science, Rehovot 76100, Israel

${ }^{b}$ Department of Archaeology and Ancient Near Eastern Cultures, Tel Aviv University, Ramat Aviv 69978, Israel

${ }^{c}$ Department of Organic Chemistry, Weizmann Institute of Science, Rehovot 76100, Israel

${ }^{\mathrm{d}}$ Honeybee Department, Ministry of Agriculture, Beit Dagan, Israel

${ }^{\text {e }}$ Bee Research Unit, National Center for Agricultural Research and Technology Transfer, Baqa' 19381, Jordan

${ }^{\mathrm{f}}$ Department of Structural Biology, Weizmann Institute of Science, Rehovot 76100, Israel
}

Received 27 March 2007 - Revised 24 May 2007 - Accepted 18 June 2007

\begin{abstract}
Beeswax is composed of fatty acids, odd numbered $n$-alkanes and wax esters. Focusing on the most stable components of beeswax, namely the $n$-alkanes, we have found by gas chromatography and gas chromatography-mass spectrometry analyses of combs from twelve colonies from Israel and Jordan that as beeswax ages and darkens its $n$-alkane composition changes. The amount of even numbered $n$-alkanes $\left(\mathrm{C}_{22}\right.$ $\mathrm{C}_{32}$ ) is significantly higher in darker colored beeswax as compared to light colored beeswax. We attribute this in part to the accumulation of cuticular residues found in the darker colored comb cells. Cuticular residues are known to contain $\mathrm{C}_{23}-\mathrm{C}_{32}$ odd and even numbered $n$-alkanes.
\end{abstract}

beeswax / color / $\boldsymbol{n}$-alkane / cuticle / GC-MS

\section{INTRODUCTION}

The most common components of beeswax are wax esters, mostly of palmitic acid in the range of $\mathrm{C}_{40}$ to $\mathrm{C}_{52}$ (Tulloch, 1970). These wax esters constitute about $70 \%$ by weight of the beeswax and have been extensively studied (Tulloch, 1980; Mills and White, 1994; Asperger et al., 1999; Aichholz and Lorbeer, 2000; Jimenez et al., 2003, 2004). The remaining components are mainly fatty acids $\left(\mathrm{C}_{16: 0}, \mathrm{C}_{18: 0}\right.$ and $\mathrm{C}_{24: 0}$; the latter serves as a biomarker) and $n$-alkanes $\left(\mathrm{C}_{23}-\mathrm{C}_{31}\right)$. The $n$-alkanes are reported to be composed almost entirely of odd numbered carbon chains with only traces of even numbered $n$-alkanes.

Corresponding author: D. Namdar, dvory.namdar@weizmann.ac.il

* Manuscript editor: Jean-Noël Tasei
Notably, all the reported analyses of alkanes in beeswax were from light colored material (Tulloch, 1970; Regert et al., 2001). The color of beeswax however varies from light yellow to dark brown and even black. The different colors roughly correspond to the different activities taking place in the cells. The newly built cells ("white") and honey-storing cells ("yellow") are located in the most peripheral areas of the hive. The brood areas ("black") are in the center of the comb. These are surrounded by the pollen-storage cells ("brown") for the nutrition of the larvae (DeGrandiHoffman, 1989). The darker color of the central area is attributed to the presence of the pupal lining residues left in this area (Hepburn and Kurstjens, 1988). The darker and hence older beeswax is also heavier and more brittle (Berry and Delaplane, 2001). Here we analyze the $n$-alkane contents of differently colored 


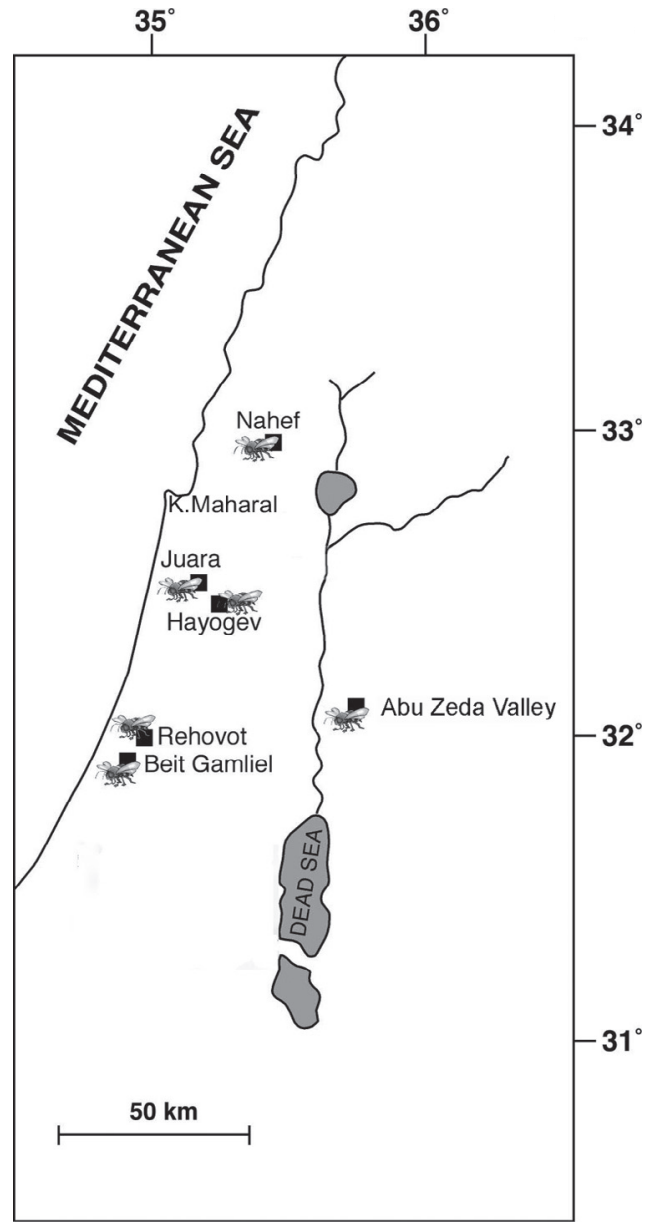

Figure 1. Schematic map of Israel and Jordan. Beeswax sample sites are marked with a bee.

beeswax from 12 natural bee hives of Apis mellifera ligustica and Apis mellifera syriaca collected in Israel and Jordan respectively.

\section{MATERIALS AND METHODS}

\subsection{Materials}

Twelve wild bee colonies were sampled from the following locations in Israel: Bet-Gamliel, Rehovot (5 different colonies of different ages), Nahef, Juara, Hayogev and Kerem Maharal (2 different colonies) and from one location in Jordan: Abu Zead valley (Fig. 1). We sampled and analyzed several combs per hive, according to their color. We generally sampled one dark and one light colored comb within each wild beehive. If the hive had a uniform color, only one comb was sampled. In the beehives from Rehovot 2 and 3, Juara, Hayogev and Kerem Maharal 2, light and dark colored beeswax were present. In the beehives from Beit Gamliel and Rehovot 4 no dark parts were found while in the hives from Rehovot 1 and 5, Nahef, Kerem Maharal 1 and Jordan very light colored parts were absent. The beehives from Nahef and Jordan are traditional clay mud hives maintained free of human introduction of wax foundations. Apis mellifera syriaca was identified using morphometric and DNA methods as the native bee that lived in this region before the introduction of imported bees (Haddad and Fuchs, 2004).

\subsection{Extraction of alkane fraction in beeswax}

All comb beeswax was analyzed without any additional purification steps. Two methods were used for the analysis of beeswax in order to determine whether or not the results are influenced by analytical procedures. These were based on the methods reported by Regert et al. (2001) ("method A") and Evershed et al. (1997) ("method B"). As we were interested also in detecting compounds other than alkanes, the silylation step (see below) was included. When analysing only the $n$-alkane composition of wild beeswax, methods A and B were used without carrying out the silylation step.

Method A. $5 \mathrm{mg}$ of beeswax was transferred to a sterile glass screw-top vial and $5 \mathrm{~mL}$ of dichloromethane were added and then sonicated for $5 \mathrm{~min} .100 \mu \mathrm{L}$ of the solution was transferred to another glass vial, and the solvent was evaporated under a stream of argon. $50 \mu \mathrm{L}$ of $N, O$ bis(trimethyl)silyltrifluoroacetamide, BSTFA, containing $1 \%$ trimethylchlorosilane (TMC) was added and the sample was heated to $65^{\circ} \mathrm{C}$ for 30 minutes. After the vial cooled to room temperature, the silylating reagent was evaporated under a stream of argon, and $50 \mu \mathrm{L}$ of dichloromethane was added; $5 \mu \mathrm{L}$ were injected into the gas chromatograph (GC).

Method B. Approximately $5 \mathrm{mg}$ of beeswax was transferred to a sterile glass screw-top vial and $2 \mathrm{~mL}$ of chloroform:methanol (2:1, v:v) solution were added and then sonicated for $10 \mathrm{~min} .200 \mu \mathrm{L}$ of the solution was transferred to another glass vial, and the solvent was evaporated under a stream of argon. $150 \mu \mathrm{L}$ of BSTFA containing $1 \%$ TMC was 
added and the sample was heated to $65{ }^{\circ} \mathrm{C}$ for 30 minutes. After the vial cooled to room temperature, the silylating reagent was evaporated under a stream of argon, and $100 \mu \mathrm{L}$ of cyclohexane were added; $5 \mu \mathrm{L}$ were injected into the GC.

n-Alkanes standards $\mathrm{C}_{10}-\mathrm{C}_{25}$ were obtained from Restek (A032194 Diesel Range Organics mix, Tenn/Miss). The $\mathrm{C}_{26}-\mathrm{C}_{32}$ standard was custom made.

\subsection{Analysis of alkanes by Gas Chromatography (GC) and Mass Spectrometry (MS)}

\subsubsection{Gas Chromatography (GC)}

The GC analysis was carried out using a HP6890 GC equipped with a flame ionization detector (FID) and using a split injection mode with a 1:10 split ratio. A $30 \mathrm{~m}, 0.32 \mathrm{~mm}$ ID 5\% cross-linked PhMe siloxane capillary column (HP-5) with a $0.25 \mu \mathrm{m}$ film thickness was used for separation. Helium was used as a carrier gas at a constant flow of $1.1 \mathrm{~mL} / \mathrm{s}$. The initial oven temperature was $50{ }^{\circ} \mathrm{C}$ and a heating gradient of $10{ }^{\circ} \mathrm{C} / \mathrm{min}$ was started $2 \mathrm{~min}$ after injection. Upon reaching $345{ }^{\circ} \mathrm{C}$, the run was continued for an additional $10 \mathrm{~min}$. The injection temperature was $220{ }^{\circ} \mathrm{C}$ and the FID detector temperature was $350{ }^{\circ} \mathrm{C}$. The identification of individual compounds was based on the comparison of retention times to reference standards.

\subsubsection{Gas Chromatography / Mass Spectrometry}

GC/MS measurements were carried out on another gas chromatograph (HP6890) with a massselective detector (HP5973; electron multiplier potential $2 \mathrm{kV}$, filament current $0.35 \mathrm{~mA}$, electron energy $70 \mathrm{eV}$, and the spectra were recorded every $1 \mathrm{~s}$ over the range mass to charge $(\mathrm{m} / \mathrm{z}) 50$ to 800 ). The same capillary column noted above was used. Peak assignments were based on comparisons with library spectra (NIST 1.6), spectra reported in the literature (Tulloch 1970, 1971; Tulloch and Hoffman, 1972) and by comparison of retention times of reference standards.

\subsection{Analysis of chitin by Fourier Transform Infrared Spectroscopy (FTIR)}

FTIR was performed using a Midac Corporation (Costa Mesa, CA, USA) instrument. The spectra were obtained by mixing about $0.1 \mathrm{mg}$ of sample with about $80 \mathrm{mg}$ of $\mathrm{KBr}$. The spectra were collected at $4 \mathrm{~cm}^{-1}$ resolution.

\subsection{Amino acid analysis}

Aliquots of the dry insoluble phase were hydrolyzed under $6 \mathrm{~N} \mathrm{HCl}$ vapor in vacuo for $24 \mathrm{~h}$. Following evaporation of the $\mathrm{HCl}$, the hydrolyzates were derivatized with Waters AccQ. Fluor reagent (6-aminoquinolyl-Nhydroxysuccinimidyl carbamate) that stabilizes and fluorescently labels both primary and secondary amino acids. The derivatives were then analyzed with an automatic amino acid analyzer (HP Aminoquant system). The identification and quantification of the separate amino acids is based on external standard retention times and peak areas respectively.

\subsection{Analysis of absorbance by Ultra Violet -Visible spectrophotometry (UV-vis)}

UV-vis spectra were taken on an HP 8453 diode array spectrometer. The measurements were carried out by diluting $50 \mu \mathrm{L}$ of a $0.01 \mathrm{M}$ solution of the dissolved beeswax in $2 \mathrm{~mL}$ of dichloromethane. The absorption intensity was measured at $500 \mathrm{~nm}$.

\section{RESULTS}

\subsection{Alkane composition}

Beeswax from natural honeycombs was sampled by color and analysed using GC and GC/MS. Analyses of light colored beeswax showed the presence of odd numbered $n$ alkanes (ONAs) in the range of $\mathrm{C}_{23}-\mathrm{C}_{33}$ with a clear predominance of the $\mathrm{C}_{27}$ alkane with only very small amounts of even numbered $n$ alkanes (ENAs) in the range of $\mathrm{C}_{22}-\mathrm{C}_{32}$. In the 9 light colored honeycombs the distribution patterns of the alkanes are consistent with 


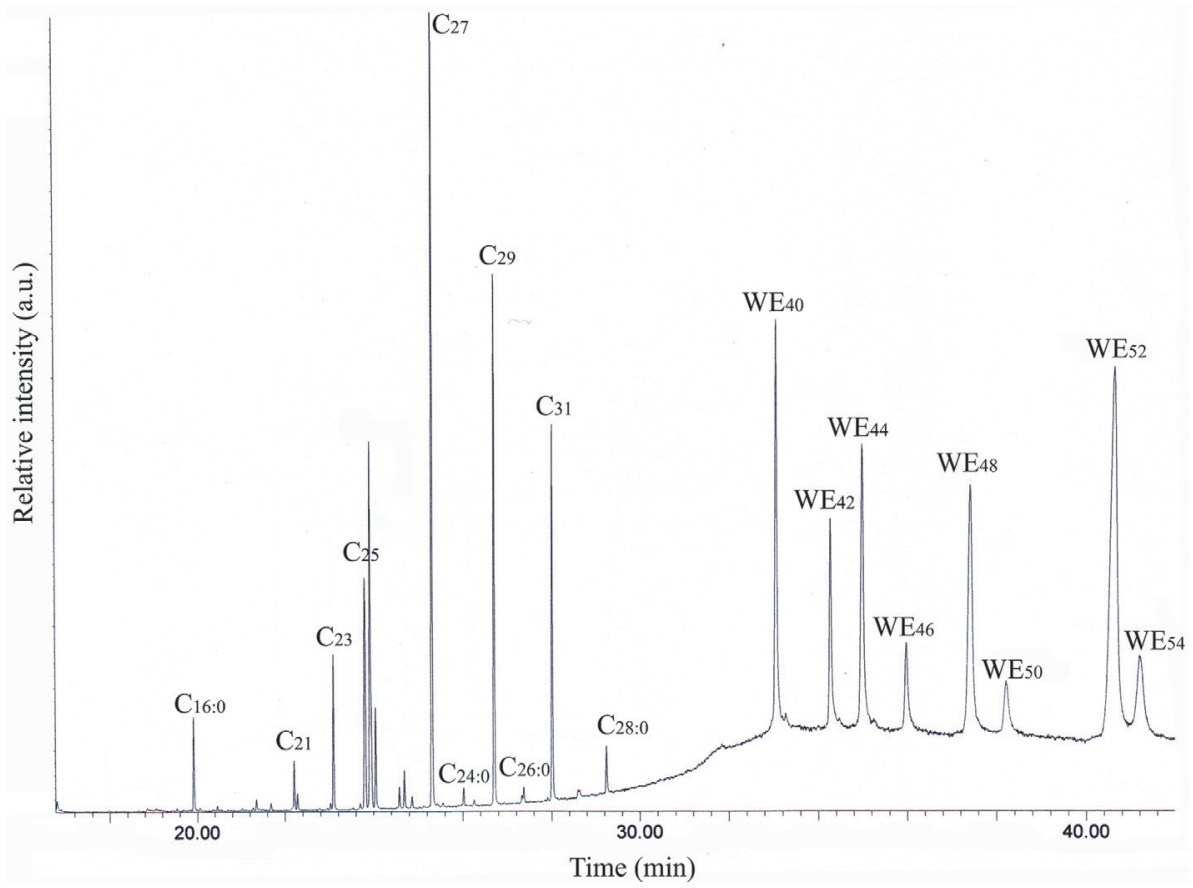

Figure 2. Representative gas chromatogram of the organic extracts from light colored beeswax from bee comb from Israel. $\mathrm{C}_{x}$ refers to $n$-alkane with $\mathrm{x}$ carbons in its chain; $\mathrm{C}_{\mathrm{x}: 0}$ refers to fatty acid with $\mathrm{x}$ carbons in its chain and 0 degree of unsaturation; WEx refers to palmitic wax esters with total of $\mathrm{x}$ carbons in the molecule; a.u. $=$ arbitrary units.

reported results (Tulloch, 1970; Hepburn and Kurstjens, 1988; Heron et al., 1994; Evershed et al., 1997; Regert et al., 2001). All other features that are attributed to beeswax were detected, but not analyzed in depth (Fig. 2). The alkanes were identified according to their mass to charge $(\mathrm{m} / \mathrm{z})$ ratios, their typical $\mathrm{m} / \mathrm{z}$ fragmentation patterns and retention times in comparison to standard alkanes.

GC and GC/MS analyses of dark colored beeswax showed an assembly of alkanes containing both odd and even numbered alkanes (Fig. 3). Darker colored beeswax (based on visual observations and absorption at $500 \mathrm{~nm}$ ) contains on average about 3 times more even numbered $n$-alkanes (ENAs) than lighter colored beeswax (Tab. I and Fig. 4). The ratios of ENAs to ONAs in different colored beeswax from the same hive also show that darker beeswax contains higher amounts of ENAs in all the hives analyzed (Fig. 5). No differences in $n$-alkane composition were observed due to the extraction method used. From this we infer that the ENAs in the beeswax might be derived from a different source, as compared to the ONAs which are derived mainly from the beeswax itself. To investigate this possibility further, we analysed other properties of beeswax by color.

\subsection{Other properties}

The absorbance of the soluble phase of the different colored beeswax varied only slightly (Tab. I). Thus we report, regarding all parameters we analyzed, solely on the two color extremes (dark and light). More than 95 weight $\%$ of the light colored beeswax dissolved in dichloromethane or in a chloroform:methanol mixture, while only 70 weight $\%$ of the dark colored beeswax dissolved in these solvents. We also noted that when two separate samples 


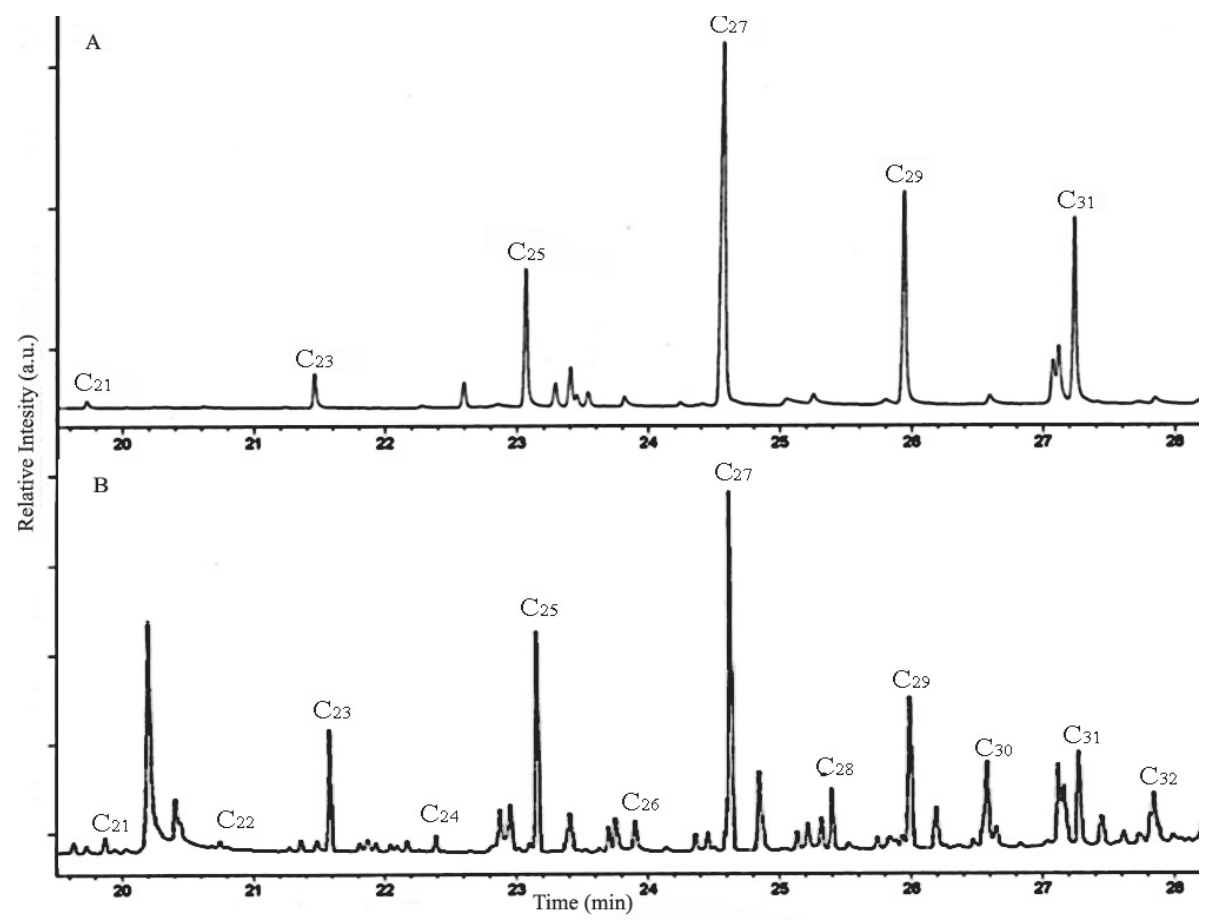

Figure 3. Gas chromatograms of the range of $n$-alkanes in the organic extracts from $\mathrm{A}$, light colored and $\mathrm{B}$, dark colored beeswax from Israel. $\mathrm{C}_{\mathrm{x}}$ refers to $n$-alkane with $\mathrm{x}$ carbons in its chain.

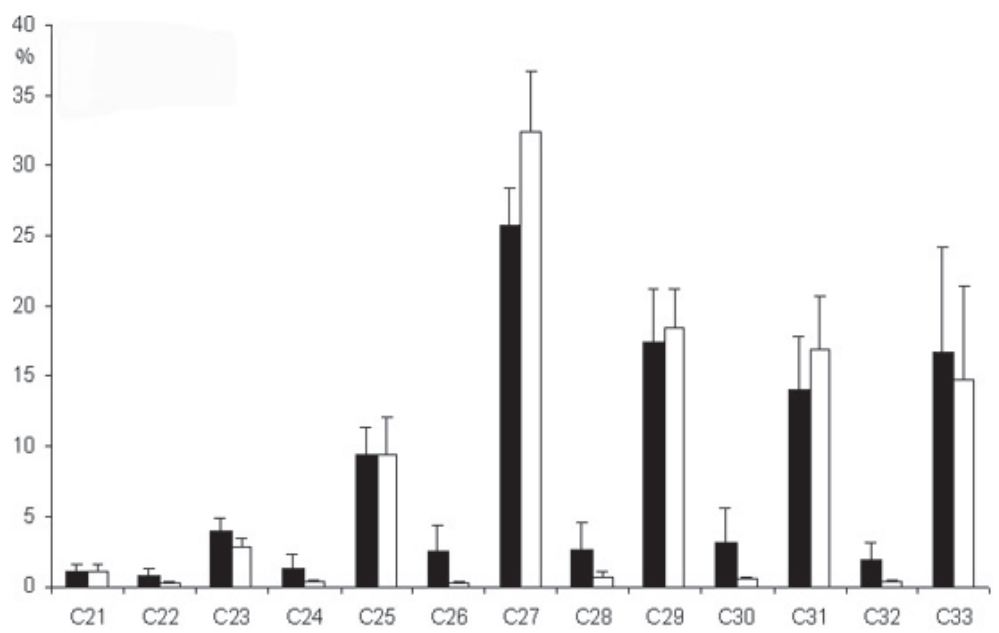

Figure 4. Histograms of averaged peak areas of the alkanes extracted from all the light colored (white columns) and dark colored (black columns) beeswax samples. The relative peak areas are normalized to the most abundant alkane. $\mathrm{C}_{\mathrm{x}}$ refers to $n$-alkane with $\mathrm{x}$ carbons in its chain. $\mathrm{Y}$ axis $=\%$. 
Table I. Odd to even numbered alkanes ratio, weight loss percentage and spectrophotometric analyses of dark and light colored beeswax.

\begin{tabular}{lccccc}
\hline Dark colored beeswax & \multicolumn{7}{c}{ \% } & & & \\
\hline Origin of comb & \% ONAs & \% ENAs & ENAs/ONAs & \% weight loss & Absorbance \\
\hline Jordan & 91.8 & 8.2 & 0.1 & 33 & 0.21 \\
Kerem Maharal 2 & 95.2 & 4.8 & 0.05 & 21 & 0.11 \\
Kerem Maharal 1 & 83.2 & 16.8 & 0.2 & 24 & 0.14 \\
Rehovot 2 & 91.9 & 8.1 & 0.1 & 24 & 0.12 \\
Rehovot 1 & 94.0 & 6.0 & 0.1 & 26 & 0.04 \\
Rehovot 5 & 91.0 & 9.0 & 0.1 & 28 & 0.05 \\
Juara & 91.6 & 8.4 & 0.1 & 32 & 0.2 \\
Hayogev & 89.3 & 10.7 & 0.1 & 34 & 0.25 \\
Nahef & 94.0 & 6.0 & 0.1 & 35 & 0.1 \\
average & 91.3 & 8.7 & 0.1 & 28.5 & 0.14 \\
Std. deviation & 3.5 & 3.5 & 0.04 & 5.1 & 0.04 \\
\hline Light colored beeswax & & & & & \\
\hline Jordan & 96.1 & 3.9 & 0.04 & 2 & 0.01 \\
Kerem Maharal 2 & 96.9 & 3.1 & 0.03 & 2 & 0.02 \\
Kerem Maharal 1 & 95.8 & 4.2 & 0.04 & 3 & 0.01 \\
Rehovot 2 & 97.6 & 2.4 & 0.02 & 2 & 0.01 \\
Rehovot 3 & 96.8 & 3.2 & 0.03 & 2 & 0.01 \\
Rehovot 5 & 98.3 & 1.7 & 0.02 & 2 & 0.02 \\
Juara & 97.2 & 2.8 & 0.03 & 4 & 0.01 \\
Beit Gamliel & 97.2 & 2.8 & 0.03 & 3 & 0.01 \\
Hayogev & 98.3 & 1.7 & 0.02 & 3 & 0.01 \\
average & 97.1 & 2.9 & 0.03 & 2.5 & 0.01 \\
Std. deviation & 0.9 & 0.8 & 0.01 & 0.7 & 0.004 \\
& & & & & \\
\hline Cuticles & 93.1 & 6.9 & 14 & 40 & 0.02 \\
\hline
\end{tabular}

$\%$ ONAs and \%ENAs was calculated from the calibrated peak area of the different alkanes present in the beeswax extract. \% weight loss is the amount (mg) of insoluble pellet left after dissolving the beeswax sample with organic solvents compared to the initial weight of the beeswax sample. Absorbance is calculated at $500 \mathrm{~nm}$ wavelength.

(approximately $40 \mathrm{mg}$ each) of light and dark colored beeswax were maintained in separate open vials at $80{ }^{\circ} \mathrm{C}$ in an incubator for 30 days, the dark and light phases separated after the samples were rapidly cooled. The heated light colored beeswax contained mostly a white phase with a very thin dark layer at the bottom of the vial. The heated dark colored beeswax contained mostly dark viscous material with a thin hard white crust on top. These observations imply that non-waxy material is present in significant amounts in the dark colored beeswax, whereas it is present in only small amounts in the light colored beeswax.

FTIR analysis of the insoluble fraction of all the beeswax samples showed the presence

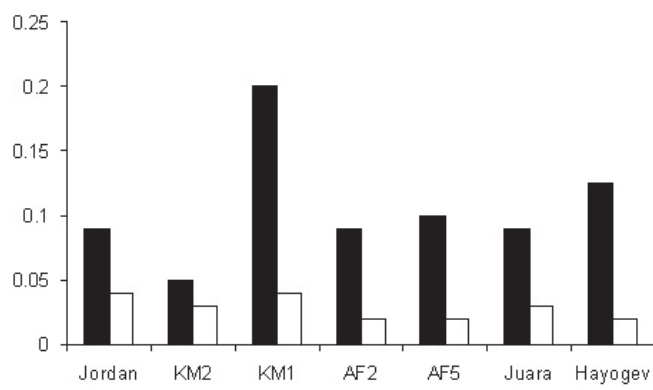

Figure 5. Histograms of the total ENAs/ONAs ratios in beeswax from seven hives in Israel and Jordan. White columns $=$ ratio in light colored beeswax. Black columns $=$ ratio in dark colored beeswax. $\mathrm{KM}=$ Kerem Maharal. $\mathrm{AF}=$ Rehovot (Faculty of Agriculture). 


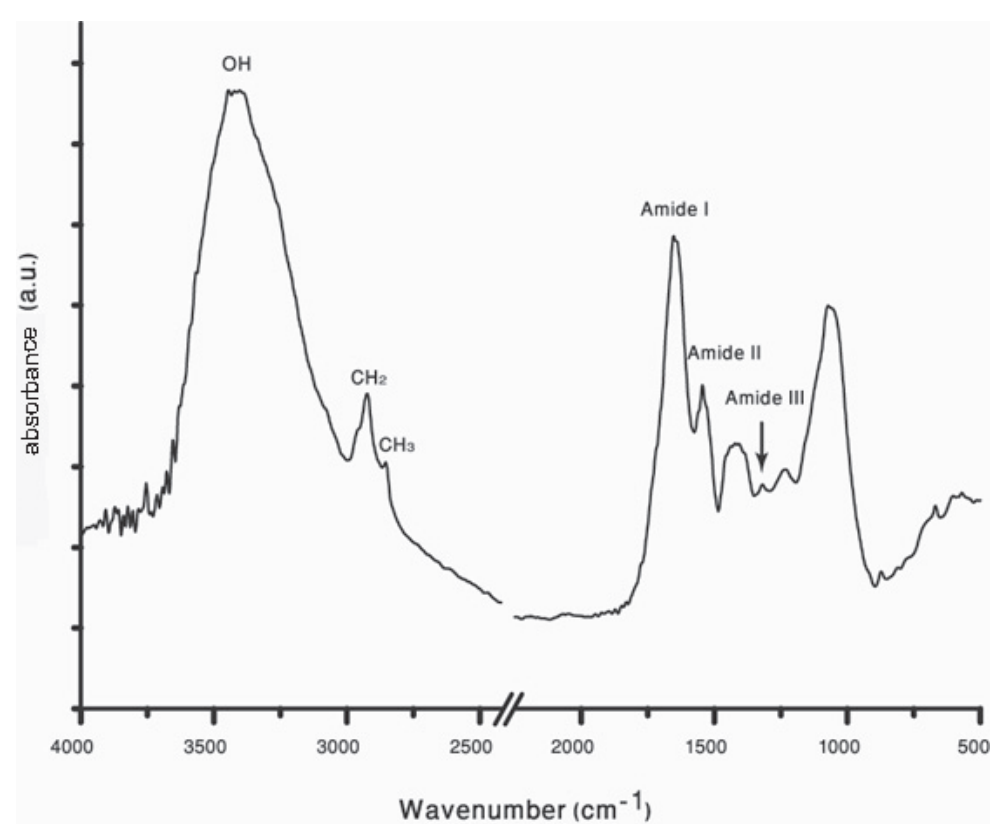

Figure 6. Infrared absorption spectrum of the insoluble fraction of dark colored beeswax showing the presence of chitin. of chitin (Amide I at $1650 \mathrm{~cm}^{-1}$, Amide II at $1544 \mathrm{~cm}^{-1}$, Amide III at $1318 \mathrm{~cm}^{-1}$, sugar ring at $1073 \mathrm{~cm}^{-1}$ ) (Fig. 6). Amino acid analyses of samples from various parts of the hives showed larger amounts of amino acids in the darker parts of the hive.

\section{DISCUSSION}

The chemical composition of light colored beeswax has been extensively investigated and its predominantly odd numbered $n$-alkanes assemblage is well documented (Tulloch, 1980; Lockey, 1988; Hepburn et al., 1991; Asperger et al., 1999; Aichholz and Lorbeer, 2000). The fact that bees use different parts of the comb for different purposes and that the central part is usually used for brood rearing is also well known (Hepburn and Kurstjens, 1988; Hepburn et al., 1991, Berry and Delaplane, 2001). Furthermore, hydrocarbon assemblages containing both odd and even numbered $n$-alkanes are known to be deposited on the surfaces of the cuticles of bees' exoskeletons (Jay, 1963; Blomquist and Jackson, 1973; Hepburn and Kurstjens, 1988). Salvy et al. (2001) report using GC and GC/MS analyses that extracts of waxes from the surface of bees' cuticles contain odd and even $n$-alkanes in the range of $\mathrm{C}_{22}-\mathrm{C}_{32}$. We confirmed this observation using cuticles obtained from two dark colored beeswax samples. We however did not obtain the relatively high concentrations of ENAs compared to ONAs that Salvy et al. (2001) reported. This could be due to pest infestation of these bees by Varroa jacobsoni (Salvy et al., 2001). Cuticular hydrocarbons are synthesized during the nymphose phase in the haemolymph of the bees, secreted immediately after molting and are incorporated into their cuticular lipids (Blomquist and Jackson, 1973; Lockey, 1988). Therefore, we can conclude that the larger amounts of ENAs present in the dark colored beeswax compared to light colored beeswax can be correlated to the accumulation of cuticles in these parts of the hives. This conclusion is consistent with the presence of chitin and protein in the fraction extracted from dark colored beeswax. Nevertheless, the absorption of different colors at $500 \mathrm{~nm}$ by beeswax, showed no correlation with the ONA/ENAs ratios (Tab. I). This lack of correlation indicates that there may be other factors that contribute to the dark color in the brood rearing areas. The amino acid 
composition of both light and dark colored beeswax is not dominated by Glycine and Alanine, showing that silk was not a major component of the protein fraction we analysed.

We thus envisage the following scenario for the presence of larger amounts of ENAs in dark colored beeswax. Cuticular hydrocarbons are synthesized during the pupal phase in the haemolymph of the bees. During the regular use of the comb by the bees, cuticles with their waxy layers accumulate, leaving their traces in the beeswax (Jay, 1963). As a result the beeswax characteristics change. Its color darkens, it becomes brittle and heavier, the cell size decreases and the chemical composition of the comb changes (Hepburn and Kurstjens, 1988). The ENAs secreted by the bee onto its cuticle, are incorporated into the beeswax. These are extracted from the whole lipid assemblage of the dark colored beeswax. The decrease in cell size causes the bees to lay their eggs in lighter colored cells, and thus the darkened areas in the hive enlarge with time (McLellan, 1978; DeGrandi-Hoffman, 1989). In the old comb ENAs are found all over the hive in increasing amounts. Because the source of the ENAs in the beeswax is additive in nature, the relative amounts of ENAs compared to the ONAs are variable, as we have observed. One implication of this observation is that in order to obtain representative analyses of parts of the comb or the whole comb, it is essential to homogenize the sample well prior to analysis.

\section{ACKNOWLEDGEMENTS}

We thank Arnon Dag from the Volcanni Agricultural Research Center. We also thank the Kimmel Center for Archaeological Science and Tel Aviv University for their financial support, as well as Mr. George Schwartzmann, Sarasota, Florida. S.W. is the incumbent of the Dr. Trude Burchardt professorial chair of Structural Biology. R.N. is the Rebecca and Israel Sieff Professor of Organic Chemistry.

Variations de la composition en alkanes entre la cire d'abeilles de rayons de coloration foncée et celle de coloration plus claire.

Apis mellifera / cire d'abeille / couleur / -alkane / cuticule / chromatographie phase gazeuse / spectrométrie de masse
Zusammenfassung - Unterschiede in der Zusammensetzung von Kohlenwasserstoffen auf Waben mit dunklem und hellem Bienenwachs. Die Hauptbestandteile von Bienenwachs sind fettlösliche Substanzen wie Fettsäuren, langkettige Alkohole, geradzahlige n-Alkane und Wachsester (Tulloch, 1970; Aichholz and Lorbeer, 2000). Wir untersuchten die Zusammensetzung der $n$-Alkane in unterschiedlich gefärbtem Bienenwachs. Die Farbveränderungen der Wabe sind von der Brutaktivität abhängig und die dunkle Farbe soll durch eine Anhäufung von Resten der Nymphenhäutchen verursacht werden (Jay, 1963, Hepburn and Kurstjens, 1988; Hepburn et al., 1991; Berry and Delaplane, 2001). Gaschromatographie (GC) und GC-Massenspektrometrie wurden für die Analysen eingesetzt (Evershed et al., 1997; Regert et al., 2001). Wie bestätigten, dass helles Bienenwachs vor allem ungeradzahlige Alkane enthält. Überraschenderweise stellten wir fest, dass das dunkle Bienenwachs zusätzlich zu den ungeraden Alkanen durchschnittlich drei Mal mehr geradzahlige Alkane enthält (Abb. 3 und 4). Die Quelle für die geradzahligen Alkane im dunkleren Bienenwachs sind sehr wahrscheinlich die Wachse auf der Bienenkutikula, die sich im Bereich des Brutnestes anreichern. Es ist bekannt, dass diese Kutikulawachse sowohl geradzahlige als auch ungeradzahlige Alkane enthalten (Salvy et al., 2001). Dieser neue Befund zeigt, dass unterschiedliche Aktivitäten der Bienen innerhalb des Bienenvolkes Auswirkungen auf die Zusammensetzung des Bienenwachses haben (Hepburn and Kurstjens, 1988; Berry and Delaplane, 2001).

Bienenwachs / Farbe / $n$-Alkane / Kutikula / GCMS

\section{REFERENCES}

Aichholz R., Lorbeer E. (2000) Investigation of combwax of honeybees with high-temperature gas chromatography and high-temperature gas chromatography chemical ionization mass spectrometry. II:High temperature gas chromatography chemical ionization mass spectrometry, J. Chromatogr. A 883, 75-88.

Asperger A., Engewald W., Fabian G. (1999) Analytical characterization of natural waxes employing pyrolysis-Gas Chromatography-Mass Spectrometry, J. Anal. Appl. Pyrolysis 50, 103115.

Berry J.A., Delaplane K.S. (2001) Effects of comb age on honey bee colony growth and brood survivorship, J. Apic. Res. 40, 3-8.

Blomquist G.J., Jackson L.L. (1973) Incorporation of labelled dietary $n$-alkanes into cuticular lipids of 
the grasshopper, malenoplus sanguinipes, J. Insect Physiol. 19, 1639-1647.

DeGrandi-Hoffman G., Roth S.A., Loper G.L., Erickson Jr. E.H. (1989) BEEPOP: A honeybee population dynamics simulation mode, Ecol. Model. 45, 133-150.

Evershed R.P., Vaughan S.J., Dudd S.N., Soles J.S. (1997) Fuel for thought? Beeswax in lamps and conical cups from Late Minoan Crete, Antiquity 71, 980-985.

Haddad N.J., Fuchs S. (2004) Honeybee agrobiodiversity: a project in conservation of Apis mellifera syriaca in Jordan, Uludag Bee J. 3, 116-120.

Hepburn H.R., Kurstjens S.P. (1988) The combs of honey bees as composite materials, Apidologie 19, 25-36.

Hepburn H.R., Bernard R.T.F., Davidson B.C., Muller W.J., Lloyd P., Kurstjens S.P., Vincent S.L. (1991) Synthesis and secretion of beeswax in honeybees, Apidologie 22, 21-36.

Heron C., Nemcek N., Bonfield K.M., Dixon D., Ottaway B.S. (1994) The chemistry of Neolithic beeswax, Naturwissenschaften 81, 266-269.

Jay C.S. (1963) The development of honeybees in their cells, J. Apic. Res. 2, 117-134.

Jimenez J.J., Bernal J.L., Aumente S., Toribio L., Bernal J. (2003) Quality assurance of commercial beeswax. Part II. Gas chromatography electrom impact ionization mass spectrometry of alcohols and acids, J. Chromatogr. A 1007, 101-116.

Jimenez J.J., Bernal J.L., Aumente S., del Nozal M.J., Martin M.T., Bernal J. (2004) Quality assurance of commercial beeswax. Part I. Gas chromatography electrom impact ionization mass spectrometry of hydrocarbons and monoesters, J. Chromatogr. A 1024, 147-154.

Lockey K.H. (1988) Lipids of the insect cuticle: Origin, composition and function, Comp. Biochem. Physiol. 89 B, 595-645.

MacLellan A.R. (1978) Growth and decline of honeybee colonies and interrelationships of adult bees, brood, honey and pollen, J. Appl. Ecol. 15, 155157.

Mills J.S., White R. (1994) The Organic Chemistry of Museum Objects, Butterworth-Heinemann, London.

Regert M., Colinart S., Degrand L., Decavallas O. (2001) Chemical alteration and use of beeswax through time: Accelerated ageing tests and analysis of archaeological samples from various environmental contexts, Archaeometry 43, 549-569.

Salvy M., Martin C., Bagneres A.G., Provost E., Roux M., Le Conte Y., Clement J.L. (2001) Modifications of the cuticular hydrocarbon profile of Apis Mellifera worker bee in the presence of the ectoparasitic mite Varroa jacobsoni in brood cells, Parasitology 122, 145-159.

Tulloch A.P. (1970) The composition of beeswax and other waxes secreted by insects, Lipids 5, 247 258.

Tulloch A.P. (1971) Beeswax: structure of the esters and their component hydroxy acids and diols, Chem. Phys. Lipids 6, 235-265.

Tulloch A.P. (1980) Beeswax - Composition and Analysis, Bee World 61, 47-62.

Tulloch A.P., Hoffman L.L. (1972) Canadian beeswax: analytical values and composition of hydrocarbons, free acids and long chain esters, J. Am. Oil Chem. Soc. 49, 696-699. 